\title{
Apartment Wanted
}

\author{
By MAREN BUVARP AARDAL
}

It seems like everybody, in fiction and in real life, dreams of having an apartment. At their disposal and that of their loved ones, away from the poor quarters that lack basic services

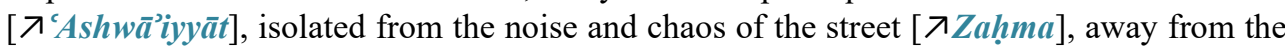
mother-in-law or neighbour who might interfere in whatever they are doing (Nawwāra, YT

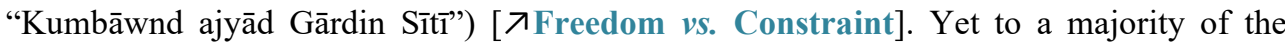
population, the dream of owning an apartment — be it in a compound [ $\nearrow$ Gated Communities / Compounds] or in the city - is hardly realizable. In Tunisia, banks require 20 per cent owner's capital in order to grant a mortgage loan, and many people find it difficult to set aside money from an already low salary (HuffPost Tunisie). In Egypt, even renting is difficult. In the more expensive neighbourhoods of Cairo, such as Zamalek, Garden City and Maadi, apartments are rented out in dollars; the equivalent value in Egyptian pounds changes every day [ 7 Dollar Crisis]. Young Tunisians often live with their parents until they marry, at the average age of 30 (ZRIBI) [ $\nearrow$ Young vs. Settled]. Whereas the economic crisis often prevents people from living on their own, Tunisians do not necessarily rush into marriage. To many, financial autonomy and work and life experience often come before the need of entering wedlock.

As it is illegal for unmarried couples to rent a hotel room or to live together, an alternative market flourishes $[\lambda$ Normality $=$ Heroism (Surviving)]. Young Tunisian couples resort to a "locale," a place for youth to have premarital sex [ $\nearrow$ Male vs. Female]. The currency being social capital, you become extremely popular in the group if you can provide your friends with an empty apartment, be it your sick grandmother's vacant house or the apartment of your friend who is studying in France. But stay cautious: neighbours might report on the illegal concubinage to the police, who seem eager to haunt the lovers (RIHAB) [ $\nearrow$ The Honourable Citizen].

Not new in either place, the same phenomenon exists in Egypt, known informally as mukna (in the slang word, never heard in official, 'decent' contexts, the standard language words makān "place" and 'imkāniyya "opportunity" and/or mumkin "possible" seem to have merged, implying "locale, love-nest, place where you can have sex") or, more formally and raising less suspicion, as "furnished apartment" (shaqqa mafrūsha) [ オLanguage]. Here you more often get paid in pounds than with social capital, but the concept is the same: the rental of an apartment for a romantic evening or even night. Some people claim that the popularity of these apartments has skyrocketed since the revolutions. The numbers are impossible to verify.

However, what has become more common in recent years is to rent an apartment together with friends. Facebook groups such as Cairo Scholar and websites such as Open Sooq and Craigslist list all kinds of apartment and room options and rules: "Male only," "visitors not allowed," "no bawwāb," "24/7 security," "open-minded flatmates," "foreigner females only," "bawwāb is cool with visitors," and so on. In general, there seem to be more rules and restrictions for women than for men [ $\nearrow$ Male $v$ s. Female]. 
Whereas both the Egyptian and Tunisian authorities report high unemployment rates, especially among university graduates, and state their intention to fight these, commentators in both countries point to income inequalities and variations in the quality of life as the main problems standing in the way of decent housing for all. As Mabrouka M'Barek, a former member of Tunisia's elected Constituent Assembly, states:

Recovering dignity is not contingent on job opportunities [...] Rather, dignity is conditional on decreasing the private debt burden, ensuring access to water, electricity, housing, and health care [...]. (M'BAREK)

It is hard to see that President Sisi's declarations of the "Year of the Youth" ('âm al-shabāb) and his repeated promises of housing projects for the youth are helping in any way. When summarizing the achievements of his two-year-old reign, the first thing he mentions is the building of one million apartments ('ABD-AL-RAHMĀN). But where are these apartments? The promise of one million apartments in 13 different cities by 2020 was announced last year, but apparently only two cities, Obour and Badr, are prioritized and the number of units is reduced to 100,000 in this first phase (ESTERMAN). In another speech, Sisi states that every youth who fulfils the relevant criteria and applies for government housing will get it, even if the number of applicants exceeds the planned 100,000 units (madàMașr). Oh, these promises. Many of the private and state-owned media outlets enthusiastically report on every new speech making new promises or celebrating achievements. But when the army rolls out a several kilometre-long red carpet for Sisi's car on his way to inaugurate a low-income housing project in 6th October (a satellite city in the Western desert, $30 \mathrm{~km}$ from Cairo), even pro-Sisi media express disapproval (Egypt Independent). Such extravagance is not exactly in line with the austerity measures Sisi demands from "his" people. Things do not look good either when the President suggests that Egyptians sponsor development projects by giving the change left over in bank transactions to the state and that they should not complain about the increase in bills for water and electricity, now that the state is no longer able to subsidize these. What spare change (MAHFOUZ)?

\section{Related Entries}

ARraYs - 'Ashwā'iyyāt $\downarrow$ Dollar Crisis $\downarrow$ Gated Communities / Compounds $\downarrow$ The Honourable Citizen $\checkmark$ Language $\downarrow$ Zahma

CODES - Freedom vs. Constraint $\diamond$ Male vs. Female $\diamond$ Young vs. Settled

CODES COLLAPSED - Normality $=$ Heroism (Surviving)

\section{References}

\section{Written Sources and Videos}

'ABD AL-RAHMĀN, 'Amr. "'Iḥmī wațanak': injāzāt al-Sīsī khilāl 'āmayn ghayr masbūqa min sinīn.” AlȚalī'a: shabakat manbar al-kalima al-hurra al-ikhbāriyya, 2016, <https://www.altaly3anews.

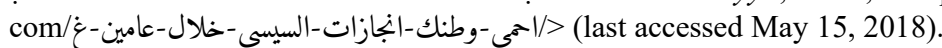

[Egypt Independent $=$ ] N. N. "Army responds to president's 'red carpet' reception saga." Egypt Independent, February 8, 2016, <https://www.egyptindependent.com/army-responds-president-sred-carpet-reception-saga $>$ (last accessed May 15, 2018). 
Esterman, Isabel. "After year-long wait, Arabtec reaches deal with Egypt on mega-housing project". MadaMasr, July 27, 2016, <https://www.madamasr.com/en/2015/04/02/feature/economy/afteryear-long-wait-arabtec-reaches-deal-with-egypt-on-mega-housing-project/amp/> (last accessed August 6, 2018).

[HuffPost Tunisie =] N. N. "L'achat d'un logement, impossible pour une majorité de Tunisiens". HuffPost Tunisie, October 7, 2016, <https://www.huffpostmaghreb.com/2016/10/07/logementtunisie_n_12383686.html $>$ (last accessed May 15, 2018).

[MadàMaṣr =] N. N. "Sisi: Don’t listen to anyone but me.” MadàMaṣr, July 27, 2016, <https://www. madamasr.com/en/2016/02/24/news/u/sisi-dont-listen-to-anyone-but-me/amp/> (last accessed May 15, 2018).

MAHFOUZ, Heba Farouk. "Egyptian president's solution for crumbling economy: Spare change." The Washington Post, September 29, 2016, <https://www.washingtonpost.com/news/worldviews/ $\mathrm{wp} / 2016 / 09 / 29 /$ egyptian-presidents-solution-for-crumbling-economy-spare-change/> $\quad$ (last accessed May 15, 2018).

M'BAREK, Mabrouka. «Enough with the 'Jasmine Revolution' narrative: Tunisians demand dignity». Middle East Eye, April 18, 2016, <https:/www.middleeasteye.net/columns/enough-jasminerevolution-narrative-tunisia-faces-many-challenges-1320408507> (last accessed September 2, 2018).

RiнAB. "Tunisie: Quand la chasse aux couples non mariés pratiquée par une frange de la société et permise par l'Etat tue". HuffPost Tunisie, August 1, 2016, <https://www.huffpostmaghreb.com/ 2016/08/01/tunisie-chasse-couple_n_11296512.html> (last accessed August 5, 2018).

[YT "Kumbāwnd ajyād Gārdin Sîtî" = ] N. N. "Kumbāwnd ajyād Gārdin Sītî". YouTube video, uploaded by Agyad Multi Projects on March 21, 2016, <https://www.youtube.com/watch?v= SS27GSskhh8\&feature=youtu.be $>$.

ZRIBI, Sofiane. "Jeunes tunisiens : l'appel du large ou l'appel des cafés". Leaders. November 28, 2016, $<$ http://www.leaders.com.tn/article/21090-jeunes-tunisiens-l-appel-du-large-ou-l-appel-des-cafes $>$ (last accessed August 6, 2018).

Films

Nawwāra (Nawara). By Hāla Khalīl (Hala Khalil). Egypt 2016.

4 marenaardal@gmail.com • 